\title{
Aspects regarding the influence of the family and the social peer group on drug use in a lot of pupils and students from Bucharest
}

DOI: http://doi.org/10.26758/9.1.15

Adina BACIU

\section{“Francisc I. Rainer" Anthropology Institute of the Romanian Academy}

Address correspondence to: Adina Baciu, "Francisc I. Rainer" Anthropology Institute of the Romanian Academy, Academy House, 13 September Avenue, No. 13, 3 Floor, 3244 Room, $5^{\text {th }}$ District, 24 C.P., Zip code 050711, Bucharest, Romania; Ph.: 04-021-175-072; Fax: 04-021-31-75-072; E-mail: adinabbaciu@yahoo.com

\begin{abstract}
Objectives. This paper aims at presenting the prevalence of illicit drug use among a group of pupils and students in Bucharest, as well as the influence of family and friends on drug use.

Material and methods. This quantitative transversal study was carried out in Bucharest between December 2017 and December 2018, with the participation of a group of 459 pupils and students from Bucharest (83 male and 376 female), aged from 14 to 23 years old. An „omnibus" questionnaire was applied, for which eight items were selected for this work. The results were statistically processed using SPSS version 21 .

Results. Out of the participants in the study, $72.9 \%$ were from organized families and $27.1 \%$ of reorganized or disorganized families. In $75.5 \%$ of cases, family relations were balanced, tense in $3.7 \%$ of cases and acceptable in $20.7 \%$ of participants. Among the subjects, $82.3 \%$ were satisfied with the relationship they had with their parents and only $1.8 \%$ were dissatisfied. There are strict family rules in $73.9 \%$ of cases and in $26.1 \%$ there are not. $84.0 \%$ respect the family rules and $16.0 \%$ do not respect them. In the circle of friends, there are $12.2 \%$ drug users, $35.5 \%$ smokers or gamblers and $34.4 \%$ alcoholic. The statistical difference is very significant $(p<0.001)$ in the sense that their number was higher among friends of study participants who have consumed an illegal drug at least once in their life.

Conclusions. This study showed that there is a large number of pupils and students from Bucharest, participants in the study, who took illegal drugs at least once in their life. In this matter, the influence of the group is very strong, although within the family there are harmonious relations, strict rules, and supervision by parents. At this age, careful supervision is required in choosing the circle of friends.
\end{abstract}

Keywords: drugs, pupils, students, family, friends.

\section{Introduction}

Drugs can be classified into two types: prohibited drugs (hallucinogens, cannabis/marijuana/hashish, cocaine, heroin, methadone, amphetamine, etc.) and legal drugs (caffeine, tobacco, ethanol/alcohol, opioids, etc.). The negative effects of illegal drugs are very severe, and they are manifested through irreversible injuries of various internal organs and through behavioural disorders affecting the social life (Bălăceanu Stolnici et al., 2012).

Consumption of legal and illegal drugs has increased since the 1970s and has become a permanent medical and psychosocial problem of the world, requiring new strategies (the National Anti-Drug Strategy 2013-2020). 
According to the European Drug Report, drafted in 2016, one in four European citizens took one time an illegal drug. Thus, one-quarter of the population in the target group, consisting of 88 million people (54.3 million men, 34.8 million women), aged between 15 and 64, tried prohibited substances at least once in their life (European Drugs Report, Trends, and Trends, 2016).

Until 1989, Romania was a transit country, and then it became a drug outlet of drug use. Consumption of illicit drugs has mainly developed in Bucharest, and there is a receptive population to try out drugs, especially heroin (Mihai, 2005).

In Romania, the consumption of any illicit drug shows twice the prevalence among young adults (the age group 15-34 years) compared to those in the general population (15-64 years), but the rates are similar to those found in the school population (16 years). Cannabis is the most consumed drug in our country, although it has the lowest values in Europe (National Report on the Drug Situation 2018).

The objectives of this paper are to present: the prevalence of illicit drug use among a group of pupils and students in Bucharest, as well as the influence of family and friends on drug use.

The hypotheses laid out at the beginning of this study are:

1. If a young person comes from a disorganized family with tense relationships, is dissatisfied with one's parents' relationship, in which one is aggrieved or neglected, such person has greater chances of taking drugs;

2. If a young person has friends that are drug users, such person has greater chances of taking drugs;

3. The family has a greater influence than friends regarding drug use.

\section{Material and methods}

This transversal quantitative study was carried out in Bucharest between December 2017 and December 2018 with the participation of a group of 459 pupils and students from Bucharest ( 83 male $-18.1 \%$ and 376 female - 81.9\%). The age of the volunteers was between 14 and 23 years old (mean age, $23.47 \pm 9.35$ years). An „omnibus” questionnaire was applied, with several themes, containing 90 items. The questions were both closed and open. In this paper we used eight items that refer to: illegal drug use in the study participant group, family organization, family atmosphere, relationships with parents, rules within the family and how to respect them, the degree of parents' interest in leisure spending by children, and the presence of illicit drug users, alcohol addicted persons, smokers and gamblers in the circle of friends.

The results were statistically processed using the Statistical Package for Social Sciences (SPSS) version 21. The statistical instrument used is the non-parametric Chi-square test.

The addition of the participants in the study is on a voluntary basis, following written, informed and freely expressed consent. The study complied with the ethical norms of scientific research, always according to the principles of anonymity and confidentiality, and the subjects can withdraw at any time in the study. The study was conducted by the Ethics Commission of the Institute of Anthropology, Fr. I. Rainer „of the Romanian Academy, number 890 / 23.11.2017. 


\section{Results}

Table 1. The distribution of the group based on drug use

\begin{tabular}{|c|c|c|c|c|c|}
\hline & & Frequency & & Valid Percent & Cumulative Percent \\
\hline \multirow{3}{*}{ Valid } & yes & 46 & 8,7 & 10,0 & 10,0 \\
\hline & no & 412 & 78,3 & 90,0 & 100,0 \\
\hline & Total & 458 & 87,1 & 100,0 & \\
\hline Missing & System & 68 & 12,9 & & \\
\hline \multicolumn{2}{|c|}{ Total } & 526 & 100,0 & & \\
\hline
\end{tabular}

\section{Frequencies}

Table 2. The distribution of the group based on gender and drug use

\begin{tabular}{|c|c|c|c|c|}
\hline \multicolumn{2}{|c|}{ Have you ever taken drugs? } & yes & no & Total \\
\hline \multirow{2}{*}{ Gender } & male & 6 & 76 & 82 \\
\cline { 2 - 5 } & female & 40 & 336 & 376 \\
\hline \multicolumn{2}{|c|}{ Total } & 46 & 412 & 458 \\
\hline
\end{tabular}

Tables 1 and 2 have demonstrated that one in 10 participants of both genders has consumed drugs, with no significant statistically difference (Pearson Chi-Square $=0.822, \mathrm{p}=$ $0.365)$.

Table 3. Distribution of the lot depending on the drug use and the way of organizing the family

\begin{tabular}{|c|c|c|c|c|}
\hline \multirow{2}{*}{ Have you ever taken drugs? } & \multicolumn{3}{|c|}{ The family is: } & Total \\
\cline { 2 - 4 } & $\begin{array}{c}\text { organized } \\
\text { (mother and } \\
\text { father) }\end{array}$ & $\begin{array}{c}\text { reorganized } \\
\text { (a parent } \\
\text { remarried) }\end{array}$ & $\begin{array}{c}\text { disorganized } \\
\text { (single parent, } \\
\text { divorce, death, others) }\end{array}$ & \\
\hline yes & 28 & 5 & 11 & 44 \\
\hline no & 300 & 20 & 85 & 405 \\
\hline Total & 328 & 25 & 96 & 449 \\
\hline
\end{tabular}

Table 3 revealed that over one-third of users of both genders came from single-parent families or reorganized families where one of the parents had remarried following the divorce or death of the other parent. Concerning drug consumption / non-consumption according to family organization, there was no statistically significant difference (Pearson Chi-Square $=3.834, \mathrm{p}=$ $0.147)$.

Table 4. Distribution of the batch according to the drug consumption and the family atmosphere

\begin{tabular}{|c|c|c|c|c|}
\hline \multirow{2}{*}{ Have you ever taken drugs? } & \multicolumn{3}{|c|}{ The family atmosphere is } & \multirow{2}{*}{ Total } \\
\cline { 2 - 5 } & $\begin{array}{c}\text { balanced, } \\
\text { harmonious }\end{array}$ & tense & acceptable & \\
\hline yes & 30 & 4 & 12 & 46 \\
\hline no & 316 & 13 & 82 & 411 \\
\hline Total & 346 & 17 & 94 & 457 \\
\hline
\end{tabular}


Table 4 shows that within the family of most study participants who consumed drugs, the atmosphere was balanced, harmonious, without high tension, and there was no statistically significant difference (Pearson Chi-Square $=4.905, \mathrm{p}=0.086$ ) between those who had consumed drugs and those who have never consumed an illegal drug.

Table 5. Drug distribution and relationship with parents

\begin{tabular}{|c|c|c|c|c|c|}
\hline \multirow{2}{*}{ Have you ever taken drugs? } & \multicolumn{4}{|c|}{ How satisfied are you with the relationship with your } & \multirow{2}{*}{ parents } \\
\cline { 2 - 5 } & satisfied & $\begin{array}{c}\text { nor satisfied } \\
\text { nor dissatisfied }\end{array}$ & $\begin{array}{c}\text { I'm not } \\
\text { satisfied }\end{array}$ & $\begin{array}{c}\text { No } \\
\text { parents }\end{array}$ & \\
\hline yes & 33 & 10 & 1 & 2 & 46 \\
\hline no & 343 & 49 & 7 & 11 & 410 \\
\hline Total & 376 & 59 & 8 & 13 & 456 \\
\hline
\end{tabular}

Table 5 showed that most of the study participants who consumed illegal drugs were content with their parenting relationships. There was no statistically significant difference (Pearson Chi-Square $=4.229, \mathrm{p}=0.238$ ) in terms of satisfaction with parenting.

Table 6. Drug distribution according to drug use and family rules

\begin{tabular}{|c|c|c|c|c|c|c|}
\hline \multirow{2}{*}{ Have you ever taken drugs? } & \multicolumn{3}{|l|}{$\begin{array}{l}\text { Are there strict rules in the family about what } \\
\text { you can do at home and outside the house? }\end{array}$} & \multirow{2}{*}{ Total } \\
\cline { 2 - 6 } & $\begin{array}{c}\text { Almost } \\
\text { always }\end{array}$ & Often & Sometimes & $\begin{array}{c}\text { Almost } \\
\text { never }\end{array}$ & Never & \\
\hline yes & 4 & 1 & 24 & 2 & 15 & 46 \\
\hline no & 30 & 60 & 216 & 7 & 95 & 408 \\
\hline Total & 34 & 61 & 240 & 9 & 110 & 454 \\
\hline
\end{tabular}

Table 6 shows that there were some rules on what study participants were allowed to do at home or outside the home, with no statistically significant difference (Pearson Chi-Square $=$ $7.864, p=0.97)$ between those who consumed drugs and those who never consumed an illegal drug.

Table 7. Drug distribution according to drug use and compliance with rules within the family

\begin{tabular}{|c|c|c|c|c|c|c|}
\hline \multirow{2}{*}{ Have you ever taken drugs? } & \multicolumn{5}{|c|}{ Do you follow these rules? } & \multirow{2}{*}{ Total } \\
\cline { 2 - 7 } & $\begin{array}{c}\text { Almost } \\
\text { always }\end{array}$ & Often & Sometimes & $\begin{array}{c}\text { Almost } \\
\text { never }\end{array}$ & Never & \\
\hline yes & 9 & 13 & 8 & 2 & 8 & 40 \\
\hline no & 129 & 101 & 92 & 13 & 44 & 379 \\
\hline Total & 138 & 114 & 100 & 15 & 52 & 419 \\
\hline
\end{tabular}

Table 7 highlighted that most of the study participants, whether they had consumed illegal drugs at least once in their lifetime or they had not consumed, often respected family rules, and there was no statistically significant difference (Pearson Chi-Square $=4.496, \mathrm{p}=$ $0.343)$. 
Table 8. Drug distribution based on drug use and parental information on leisure time

\begin{tabular}{|c|c|c|c|c|c|c|}
\hline \multirow{2}{*}{$\begin{array}{c}\text { Have you ever taken } \\
\text { drugs? }\end{array}$} & \multicolumn{5}{|c|}{ Do your parents know where and with whom do you spend } & \multirow{2}{*}{ Total } \\
\cline { 2 - 6 } & Almost always & Often & Sometimes & Almost never & Never & \\
\hline yes & 22 & 9 & 9 & 2 & 2 & 44 \\
\hline no & 239 & 72 & 70 & 15 & 2 & 398 \\
\hline Total & 261 & 81 & 79 & 17 & 4 & 442 \\
\hline
\end{tabular}

From Table 8, it was noted that parents often knew where and with whom their children spent their free time. There was no statistically significant difference (Pearson Chi-Square $=$ $8,199, \mathrm{p}=0.085$ ) between those who consumed drugs and those who never consumed an illegal drug.

Table 9. Drug distribution according to drug use in the studied group and the circle of friends

\begin{tabular}{|c|c|c|c|c|}
\hline \multirow{2}{*}{ Have you ever taken drugs? } & \multicolumn{3}{|c|}{ The circle of friends you have: - Are they drug } & \multirow{2}{*}{ Total } \\
\cline { 2 - 4 } & Yes & No & Do not know & \\
\hline yes & 22 & 21 & 3 & 46 \\
\hline no & 33 & 348 & 25 & 406 \\
\hline Total & 55 & 369 & 28 & 452 \\
\hline
\end{tabular}

Table 10. Drug distribution based on drug use and presence of smokers and gamblers in the circle of friends

\begin{tabular}{|c|c|c|c|c|}
\hline \multirow{2}{*}{ Have you ever taken drugs? } & \multicolumn{3}{|c|}{$\begin{array}{c}\text { The circle of friends you have: - are they heavy } \\
\text { smokers or gamble constantly? }\end{array}$} & \multirow{2}{*}{ Total } \\
\cline { 2 - 4 } & Yes & No & Do not know & \\
\hline yes & 31 & 12 & 2 & 45 \\
\hline no & 130 & 247 & 31 & 408 \\
\hline Total & 161 & 259 & 33 & 453 \\
\hline
\end{tabular}

Table 11. Drug distribution according to drug use in the studied group and the presence of alcohol users in the circle of friends

\begin{tabular}{|c|c|c|c|c|}
\hline \multirow{2}{*}{ Have you ever taken drugs? } & \multicolumn{3}{|c|}{ The circle of friends you have:- Are they alcohol } & \multirow{2}{*}{ Total } \\
\cline { 2 - 4 } & yes & no & do not know & \\
\hline yes & 33 & 12 & 1 & 46 \\
\hline no & 121 & 250 & 33 & 404 \\
\hline Total & 154 & 262 & 34 & 450 \\
\hline
\end{tabular}

Tables 9, 10 and 11 showed that in the case of drug users who consumed illegal drugs, the number of drug and alcohol users, as well as smokers and gamblers in the circle of friends, was higher than those who did not use any illicit drug, the statistical difference being highly significant $(\mathrm{p}<0.001)$. 


\section{Discussions}

This study found that most of the participants who had consumed drugs at least once in their life came from families with a harmonious, balanced, or at least acceptable family atmosphere and were pleased with the relationship that they had with their parents.

There are risk and protection factors of drug use. Risk factors include disorganized families or groups of peers with deviant behaviour. Protective factors include harmonious family relationships, close supervision of children, rules to be respected in the family, parents actively involved in children's activities and problems (Hird et al., 1997). In Romania, empowering families to become involved in children's lives and providing them with positive models is one of the main objectives of public policies in the field of drug abuse prevention in the country (National Report on Drug Situation 2015 Romania New Developments and Trends, REITOX, p. 77), contributing to formation of young people's personality (http://referatreferate.blogspot.ro/2013/02/familia-ca-grup-social.html).

For many participants in the study, there were strict rules on what they were allowed to do at home and outside the house, rules that were most often respected. In an article, Frisher et al. (2007) showed the importance of family cohesion, but especially of parental monitoring and strict discipline rules imposed by parents on drug-related factors.

Also, in most cases, parents knew where and with whom their children spent their free time. The leisure activities are constantly changing according to age (Rada, 2017), during childhood leisure time is often under the supervision of grandparents, who can provide a positive model to children and future adolescents and young people, thus contributing to the strengthening drug protection factors (Rada, 2018).

However, a fairly high percentage of $10 \%$ has consumed drugs at least once in a lifetime. Most of them said they smoked cannabis at parties, at concerts, with friends, and the majority of the time out of curiosity. The main causes of drug use are curiosity, the desire to try something new, to experience everything, to increase intellectual performance and even the desire to be modern (Bălăceanu Stolnici et al., 2012).

From the data presented in this paper, more than half of the friends of those who have consumed illegal drugs were drug users, alcohol or smokers or constant gamblers. Thus, one in 10 study participants consumed drugs, often under the influence of the entourage.

In adolescence, the group of peers had great influence (Brown, 1989, apud Morton et al, 2010), often becoming more important than the family (Bălăceanu Stolnici et al., 2012). At this stage in life in the circle of friends, there are common interests and behaviours (Eiser et al., 1991, apud Morton et al., 2010). Frequently, to be accepted in a group of peers, the adolescent will adapt to the group's requirements (Evans, Hersey and Renaud 2006, apud Morton et al, 2010).

Even if the circle of friends or family determines drug use, they are those who have an important role in determining who should quit drug use (Baciu and Pungă, 2017).

As a result of this study, most of the participants came from peer groups in which drug, alcohol, tobacco use was common. If the family and the group of peers had unfavourable influences on the onset of drug abuse amongst the closest, most drug users who sought treatment or turned to drug-related emergency services did so at the urge of the family or friends, according to the National Report on the Drug Situation 2015 Romania presented by the National Anti-drug Agency.

It can be seen from these data that at this age curiosity, the desire to imitate friends are very high and can lead to drug use, even if the young people were supervised, educated and had no family problems. 


\section{Conclusions}

This study showed that among the pupils and students in Bucharest, the number of those who consumed illegal drugs at least once in their life was quite high.

Harmonious family relationships, good relationships with young people who participated in the study, parents' involvement in education by enforcing rules and supervising leisure were factors that determined that $90 \%$ of study participants not use illegal drugs at least once in their life.

It has also been demonstrated how strong the influence of the peer group is at this age, and that careful supervision is required in choosing a circle of friends, as well as an open, sincere communication of students and young people with their parents. Both family and friends have major influences on the consumption or non-consumption of illicit drugs.

The high percentage of subjects who took drugs at least once in their life, even if in families with positive models or harmonious relationships with parents, were closely monitored. They have respected most of the time the rules imposed and invalidate the hypothesis from which we started the study, namely that a family with problems determines drug use. We noticed that the example of friends affects the behaviour of adolescents and young people more than that offered by the family. The hypothesis expressed towards a stronger influence of the family rather than that of the friends is denied by the data obtained during this research.

Most of the participants who took drugs have also use due to the influence of friends' example or at their insistence (,to become a peer," „to be cool,” „to discover cannabis”). This proved the hypothesis formulated on the influence of the peer group on drug use.

It can be said that information on the harmful effects of drugs is absolutely necessary both among young people and among parents. Parents should not neglect this issue and should talk with children in detail, make them understand that it is not just a teenage game. But it can lead to addiction and can have many severe consequences.

\section{Bibliography}

1. Baciu, A. and Pungă, A., 2017. Ethical implications of a quantitative study that analyzes the drug consumers from a Bucharest neighborhood, Romanian Journal of Legal Medicine [25], [e-journal] Vol. XXV, 1, pp. 113-119, DOI: 10.4323/rjlm.2017.113, http://www.rjlm.ro/index.php/arhiv/546.

2. Bălăceanu Stolnici, C., Papari, C.A., Papari, A., Cozaru, G.C. and Iamandescu, I.-B., 2012. Tentaţie şi dependenţă (Tentation and addiction). Constanţa: Editura Fundaţiei „Andrei Şaguna".

3. Brown, B.B., 1989. The role of peer groups in adolescents' adjustment to secondary school. In: Berndt TJ, Ladd GW, editors. Peer relationships in child development. New York: Wiley; pp. 188-215 apud Simons-Morton, B., Farhat, 2010.Recent Findings on Peer Group Influences on Adolescent Substance Use. J Prim Prev., [e-journal] 31(4), pp. 191-208. https://doi.org/10.1007/s10935-010-0220-x.

4. Eiser, J.R., Morgan, M., Gammage P., Brooks, N. and Kirby, R., 1991. Adolescent health behaviour and similarity-attraction: friends share smoking habits (really), but much else besides. British Journal of Social Psychology, 30, pp. 339-348. [PubMed] apud SimonsMorton, B., Farhat, 2010. Recent Findings on Peer Group Influences on Adolescent Substance Use. J Prim Prev., [e-journal] 31(4), pp. 191-208. https://doi.org/10.1007/s10935-010-0220-x.

5. Evans, W.D., Powers, A., Hersey, J. and Renaud, J., 2006. The influence of social environment and social image on adolescent smoking. Health Psychology. 25:2633. [PubMed] apud Simons-Morton, B., Farhat, 2010. Recent Findings on Peer Group 
Influences on Adolescent Substance Use. J Prim Prev., [e-journal] 31(4), pp. 191-208. https://doi.org/10.1007/s10935-010-0220-x.

6. Frisher, M., Crome Macleod, J., Bloor, R. and Hickman, M., 2007.Predictive factors for illicit drug use among young people: a literature review, London: Home Office.

7. Hird, S., Khuri, E.T., Dusenbury, L. and Millman, R.B., 1997. Adolescents; Substance abuse, Third edition; Williams \&Wilkins, pp. 683-690, cited in Mihai, S.L., 2005. 14 pași în lumea drogurilor, București.

8. Mihai, S.L., 2005. 14 pași în lumea drogurilor (14 steps in the drug world), București.

9. Rada, C., 2017. Impact of some demographic parameters on leisure time and bodyweight, Anthropological Researches and Studies, [e-journal] 7, pp. 111-121. http://doi.org/10.26758/7.1.12

10. Rada, C., 2018. Spending leisure time when approaching retirement and during retirement, Rev. Psih., 64 (4), pp. 265-280.

11. ***Familia ca grup social (The family as a social group). [online] Available at: http://referat-referate.blogspot.ro/2013/02/familia-ca-grup-social.html [Accessed 22 June 2016].

12. ***Raportul național privind situația drogurilor 2018 (National report on drugs in 2018)

13. ***Raportul naţional privind situaţia drogurilor 2016-România-Noi evoluţii şi tendinţe. Reitox (National report on drugs in 2016 - Romania- New developments and trends Reitox), 2016.

14. ***Raport naţional privind situaţia drogurilor 2015 România. Noi evoluţii şi tendinţe (The National Report on drugs in 2015 in Romania.New developments and trends), European Monitoring Centre for Drugs and Drug Addiction, Agenţia Naţională Antidrog, REITOX, pp. $69,77$.

15. ***Strategia Naţională Antidrog (National Anti-Drug Strategy) 2013 - 2020. 